\title{
AFRICA'S WEST MEETS ITS SOUTH: \\ A Comparison of Democracy in Nigeria and South Africa, 1993-2016
}

\section{Dorcas Ettang and Oladapo Kayode Opasina}

\author{
Dorcas Ettang is a Senior Lecturer, School of Social Sciences \\ University of KwaZulu-Natal \\ email: ettang@ukzn.ac.za
}

\begin{abstract}
Oladapo Kayode Opasina is Visiting Scholar, Centre for Refugee Studies York University, Toronto email: kayode.opasina@gmail.com
\end{abstract}

\begin{abstract}
Democratic elections in Africa have drawn significant international interest because of their tendencies to generate conflict and violence. Unfortunately, this is not likely to change in the near future, especially with the prevalence of one-party dominance, electoral malpractices, patrimonial leadership and election violence in a number of African countries. Against this background the paper carries out a comparative analysis of presidential elections in Nigeria and South Africa between 1993 and 2016. It focuses specifically on their experiences with election violence, one-party dominance, voter dynamics, and how both countries rate against key global democratic indicators. In doing so, the underlying research question seeks to understand how both countries differ from these variables and what factors contribute to these differences. Using secondary data and responses to the National Democratic Institute (NDI) indicators, the paper argues that while both countries are key players within their respective regions, various factors are responsible for why they differ in their experiences with elections in particular and the democratic process in general. In carrying out an extensive empirical review of relevant literature, this paper is a starting point for comparing the state of democracy in two of the strongest economies on the African continent. The paper also attempts to understand the more recent and urgent experiences and the challenges of democracy in these two contexts. Finally, it presents objectives and challenges for the present and the future.
\end{abstract}

Keywords: elections, violence, democracy, political party, Nigeria, South Africa 


\section{INTRODUCTION}

Many democratic experiences on the African continent attest to significant failures. These include violence and the securitisation of elections, failed states and poor voter participation. Violent protests in Burundi and the elimination of presidential term limits in Uganda are two of the many examples that illustrate massive governance deficits, weak leadership and the failure of democratic promises. These challenges are further buttressed by challenges like poverty, unemployment and poor service delivery, all of which contribute to popular disillusionment with government. For example, poor service delivery in South Africa has resulted in various protests and clashes between security forces and disgruntled groups. Thus it can be said that South Africa reflects the widespread discontent across the continent with governmental failure or weak response to addressing the socio-economic challenges of its people. In Nigeria, struggles and political agitation preceded and interrupted the process of democratisation. These included political competition, the pursuit of patrimonial and personal interests, ethnic, communal and religious mobilisation and power. The country has also contended with military regimes throughout its democratic experience, such as those in 1966 and 1983. Nigeria faces the challenge of curbing corruption, conducting credible elections, rebuilding institutions, as well as combating poverty and crime.

While these challenges and many more are typical of most emerging democracies, Nigeria and South Africa provide significant lessons in how democracy has continued to fail or succeed. Taking these experiences into account, the main objective of this paper is to examine and assess the experiences of both countries with democracy between 1993 and 2016. The focus is in particular on Nigeria's attempt at returning to civilian rule (the Third Republic) and South Africa's liberation from the apartheid government in 1994. Both countries were dominated by one-party systems until recently. Nigeria's All Progressives Congress (APC) won the presidential election in 2015 and in 2014 South Africa's African National Congress (ANC) saw a steady decline in votes compared to previous elections. Similarly, both countries are battling with security issues ranging from crime and xenophobic attacks in South Africa, to the grave threat of Boko Haram ${ }^{1}$ in Nigeria's northeast geo-political zone. Both Nigeria and South Africa are leading powers on the continent and are dominant players at the regional level, in the Economic Community of West African States (ECOWAS) and the Southern African Development Community (SADC) respectively. The

1 Boko Haram is an Islamic Jihadist militant group, founded in 2001 and based in the Nigerian northeast geo-political zone. Boko Haram literarily means 'Western education is forbidden'. 
relationship between both countries has been defined as the 'shared confluence of economic wealth, regional dominance and political presence that is increasingly seen as the fulcrum of Africa's future' (Alden \& Soko 2005, p. 386).

This study will contribute to existing research by bringing together these two experiences of democracy on the African continent. Nigeria and South Africa are key leaders when it comes to political and security decisions on the continent, as demonstrated by decisions taken at the African Union (AU). Thus, they should be shining examples of good governance and strong democracy; however, this is not the case. This examination of both countries will shed some light on their issues and deficits with regard to elections, and on democracy in both countries. The paper will focus specifically on presidential elections, while noting that provincial/state and local government elections also play a critical role in the democratic process of both countries. The paper will contribute to the field of comparative politics by proposing key lessons and recommendations for burgeoning democracies through a joint analysis of these key political players.

Based on the objective and goals stated above, this paper therefore seeks to answer four research questions:

a. Why has the level of electoral violence been higher in Nigeria than in South Africa since 1993?

b. Why has there been an alternation in power in Nigeria but not in South Africa?

c. What factors explain the higher level of democratic indicators in South Africa than in Nigeria?

d. What factors account for lower voter apathy in Nigeria than South Africa?

The paper concludes with a discussion of political party dynamics; the role of technology in elections; the use of money in elections through vote-buying, or as it is known in Nigeria the provision of 'stomach infrastructure'; and the use of political thugs. All these elements will continue to play a significant role in the progress and strength of these democracies.

\section{METHODOLOGY}

Content analysis is the primary methodology of choice for this paper. Furthermore, in answering research questions on the level of democratic indicators, a quantitative analysis method was employed to measure which country has the higher level of democratic indicators. The paper used the National Democratic Institute (NDI) Democracy Indicators as its research instrument. 
Content analysis allows a researcher to use text to retrieve important information and make inferences based on key concepts and views in the text. For the purposes of this paper, written text will be reviewed, including discussion papers, news reports, scholarly articles and reports from key research institutions. This is in order to identify key themes and keywords to shape the discussion and examination of democracy in both South Africa and Nigeria. This process of content analysis will focus on identifying the frequency of key concepts, referred to as concept analysis, and the relationship between these concepts, also referred to as relational analysis (Babbie 2017, p. 339).

In unpacking the key research questions of this study, the following key terms will be identified and linked: electoral violence; one-party system; voter apathy; intra-party conflicts; and electoral systems. In so doing it will identify the reasons for and factors in how these variables are reflected in both Nigeria and South Africa.

The NDI Democracy Indicators as developed by J. Brian O'Day (a political party expert with NDI) assessed the following eleven indicators: civil rights, economic and social rights, civil and political participation, political parties, free and fair elections, rule of law, military and police control, government accountability, corruption, media and government responsiveness. The different items or questions under these indicators show the ratings of both countries and where they currently stand in relation to democracy. It should be noted that Freedom House, The Economist Intelligence Unit's Democracy Index, the Institute for Democracy and Electoral Assistance (International IDEA) and Bertelsmann Transformation Index (BTI) have all developed democracy and governance surveys that have guided the NDI Democracy Indicators. These indicators were sent to two respondents (one in Nigeria and one in South Africa). In both cases, the participant selection was based on purposive sampling. Purposive sampling is a type of non-random sampling 'where the researcher selects what he/she thinks is a "typical" sample' (Walliman, 2011). In Nigeria, the subject is a 40-year old female media practitioner who has a wide knowledge of the subject matter and has been reporting on matters relating to Nigerian elections for decades. In South Africa, the participant is a male South African media worker who has reported equally extensively on elections in South Africa. These individuals were selected on the basis of their extensive experience and understanding of the democratic processes in both countries. This study notes that this information is not reflective of the broader population but is meant to give some guidance on the state of democracy in these countries. 


\section{NIGERIA AND SOUTH AFRICA: COMPARISON OF THE POLITICAL, ECONOMIC, SOCIAL AND CULTURAL VARIABLES \\ Political Conditions}

A few commonalities and differences emerge when comparing the political conditions in Nigeria and South Africa. Both have strong executives with presidents sitting as heads of state and heads of government. Their strong powers are supported by the fact that in both cases their parties have a majority in their legislatures. Historically, two parties have remained politically dominant; the ANC in South Africa and the People's Democratic Party (PDP) in Nigeria. Their federal-type structures are characterised by strong central government and regional authorities consisting of states and local governments in Nigeria, and provinces and municipalities in South Africa. This delegation of powers from national to regional has proved to be successful in managing complex political systems with large and diverse populations. While both countries regard themselves as multi-party democracies with various political parties participating during elections, this has not deterred them from having a dominant one-party system. This situation has however changed, particularly in Nigeria where the opposition APC won the presidential election in 2015, the majority of seats in the Senate and the House of Representatives, and also the gubernatorial elections in 22 out of the 36 states that make up Nigeria.

Based on existing data and statistics from the 2012-2016 Corruption Index, South Africa and Nigeria have failed to improve their rankings, thus remaining as corrupt in 2016 as they were in previous years (Transparency International 2017). According to the Global Corruption Barometer (Pring 2015) citizens in Nigeria noted the high levels of corruption in public institutions, high levels of bribery and the weakness of the government's anti-corruption initiatives. In South Africa, four out of five citizens (83\%) noted that corruption has increased and other results show a negative assessment of the government's anti-corruption efforts (Pring 2015).

\section{Economic Conditions}

Both Nigeria and South Africa remain economically dominant on the continent. Nigeria is considered a key power in Africa, not only because of its population of over 182 million people (2015 estimate), but also because of its political and economic role in the region (Ploch, 2012). While South Africa's population is below the 60 million mark, it continues to hold a significant role in SADC in particular and Africa in general due to its developmental role in the region and the continent. 
Nigeria is one of the world's largest oil-producing countries and is believed to be Africa's leading oil producer. Apart from crude oil, the country boasts other mineral resources such as natural gas, bauxite, coal, tin, iron ore, limestone and zinc, most of which have so far remained either largely unexploited or are being explored by illegal miners. Despite its abundant mineral resources, a large proportion of the population still lives in abject poverty and Nigeria is grouped among the developing nations of the world. The country's GDP is estimated to be $\$ 238.9$ billion (2011 estimate), the real growth rate is put at 7.2\% (2011 estimate), and the population below the poverty line is $70 \%$ (2007 estimate) (Central Intelligence Agency, 2012). The high level of unemployment has not improved with an increase from $13.9 \%$ in the 3rd quarter to $14.2 \%$ in the 4th quarter of 2016, according to statistics released by the National Bureau of Statistics (Iroha 2017). Figures released by the National Bureau of Statistics from the 1st quarter of 2016 put unemployed youth at $42.2 \%$ (ThisDay Live).

South Africa has Africa's second largest economy, with a GDP in terms of purchasing power parity (PPP) estimated at $\$ 723.5$ billion by the 2017 Index of Economic Freedom. In spite of this there is a high unemployment rate in South Africa, currently sitting at approximately $27.7 \%$, the highest unemployment rate in the county since September 2003 (Statistics South Africa, 2017). Youth unemployment rate also rose to $38.6 \%$ in the first quarter of 2017 (Statistics South Africa, 2017).

In addition, areas of concern include the high levels of poverty and crime, and poor access to infrastructure and basic services. According to the 2017 Index of Economic Freedom, South Africa sits at $62.3 \%$ and Nigeria at $57.1 \%$ where these are concerned. Protection of property rights is weaker in Nigeria (35.3\%) than in South Africa (67.6\%) (2017 Index of Economic Freedom). In addition, the effectiveness of the South African judiciary (59.7\%) and the integrity of its government $(47.6 \%)$ are rated as being higher than in Nigeria where they are rated as $33.2 \%$ and $12.2 \%$ respectively.

\section{Social and Cultural Conditions}

South Africa still struggles with disparities of a racial nature, and Nigeria of an ethnic and religious nature, all inherited from pre-independence times. These identities continue to shape and determine political, social, and economic interactions and dynamics in both countries, and are reflected in gross disparities in wealth and other inequalities. Nigeria's most glaring political threat is that of Boko Haram, an Islamist group that has both threatened and disrupted the peace and security of the country in the name of trying to Islamise the nation. South Africa's racial dissent has not reached the same level of heightened insecurity 
and increased state of chaos as Nigeria, even though racial inequalities and sentiments are felt in various social, economic and political spaces. In Nigeria, current incidences of ethno-religious violence and identity conflicts threaten peace and security in the country on a regular basis. These include the ethno-religious violence in Plateau State, inter-ethnic clashes and attacks on innocent civilians in the northern part of the country (Adamawa and Borno States) and increased cases of kidnapping that speak of the fragile peace in the country.

\section{THEORETICAL UNDERPINNINGS}

According to Omodia (2009, p. 38), democratisation processes that took place in most African states in the 1990s were geared towards liberal western democracy. This emphasises the following:

- Competitive party politics through constitutionally recognised opposition

- Entrenched fundamental human rights through which the citizens could exercise political participation in the political system

- The existence and adherence to the principle of the rule of law that must guide functional conflicts regarding the processes for acquisition of power

- An independent electoral body that should be free from the influence of governmental officials and must be viewed as credible by competing parties

- The principle of political equality which respects the notion of one man, one vote and where the votes of the electorate count

- The notion of free and fair elections, where the electorate are neither intimidated nor insecure when participating in elections.

However, in reality these liberal democratic elements seem to be lacking in contemporary elections, particularly in Nigeria and South Africa. As mentioned earlier, issues like one-party dominance, electoral malpractices and violence hinder the growth of democracy in both countries.

Elections in emerging democracies are increasingly important components in the efforts to manage conflict, and also in facilitating political reform and economic growth (Long 2010). Democracies are known as systems that produce free and fair elections. Democracy also gives citizens the right to vote and align themselves with any political party. Baker (1999) and Southall (2000) further note four critical themes to audit democratic performance within the African context. These are: electoral processes, a transparent and accountable government, civil and political rights, and a society that guarantees freedom of speech and equal rights. 


\section{COMPARATIVE ANALYSIS}

The cases of Nigeria and South Africa provide insights into elections, democracy and violence in burgeoning democracies. This section delves further into a comparative exercise of both countries examining four key variables: electoral violence, one-party dominance, democratic indicators and voter dynamics.

\section{Electoral Violence}

This section explores why electoral violence is higher and more destructive in Nigeria than in South Africa. In so doing it examines incidences and forms of electoral violence, performance and perceptions of electoral institutions, actors involved in electoral violence and the reasons for their participation in these two countries.

\section{Incidence and forms of electoral violence}

According to Okafor (2015, p.2) electoral violence could be regarded as an 'elections-motivated-crisis employed to alter, change or influence by force or coercion, the electoral behaviour of voters or voting patterns or possibly reverse electoral decision in favour of particular individual, groups or political party'. Using this definition, electoral violence has occurred in both Nigeria and South Africa, although to varying degrees. In the build-up to the 2015 general elections in Nigeria there were the usual tensions that have been the trademark of elections in most of its history. Violence was witnessed during campaign rallies months before the general elections. There were re-run elections in some areas that witnessed disruptions and manipulations. Okafor $(2015$, p. 2) gives some statistical analysis of electoral violence in Nigeria as follows:

According to IFES Reports (2007), there were 967 incidents of electoral violence in the 2007 elections. Cases of abduction and kidnapping, murder and killing protest, disruption, intimidation and physical attack as well as poster defacing all featured in the incidents. 300 people were killed on issues relating to 2007 elections. Deadly election-related and communal violence in northern Nigeria following the April 2011 Presidential voting left more than 800 people dead.

Human Rights Watch (2011)

As is typical in many developing democracies, violence often features during pre- and post-democratic elections. Ploch $(2012$, p. 7) observes: 
Violence prior to the 2011 elections (in Nigeria) included clashes between party supporters and several assassinations. Poll-related security concerns were further heightened by a spate of bombings during political rallies, predominantly in Bayelsa state in the Niger Delta region. There were at least six bombings in April in the northeast state of Borno, where Boko Haram, a local militant Islamist group, has been most active. Boko Haram claimed responsibility in January 2011 for the assassination of the state's leading gubernatorial candidate and several of his supporters.

A review of electoral violence in South Africa shows more focus on inter-party tensions, insults and accusations amongst parties rather than the intense and violent clashes that have occurred in Nigeria. Cilliers and Aucoin (2016) note that South Africans have voted peacefully since 1994. In 1999 the level of electoral violence was less than in 1994 with a recorded number of 83 deaths, taking place mainly in the province of KwaZulu-Natal as a result of political chaos four months before the elections (Southall 2000, p. 152). In the 2014 elections, violence broke out on 8 May as a result of residents finding two dumped ballot boxes. Marais (2010) noted that $21^{\text {st }}$ century South Africa is characterised by the disappearance of political violence. Cilliers and AuCoin (2016) also note that election violence was not a significant element during the 2014 elections, apart from threats made to the Independent Electoral Commission (IEC). Political violence then was not as serious as it had been prior to the 1994 elections, according to political analyst Aubrey Matshiqi (Powell, 2016). Nonetheless, political intimidation does take place during South Africa's political elections. According to Bruce (2014) its most common forms include: 'manipulating people using misinformation and threats regarding pensions and grants, interfering with access to meeting facilities, the disruption of meetings, assaults and threats of physical harm and punishing people who associate with rival political parties through the denial of jobs, contracts, services and development opportunities.' While these threats might not lead to actual physical violence or human casualties, the danger they pose should not be downplayed as they threaten the ideal that individuals are free to elect whoever they choose and also threaten the physical, economic and social security of individuals.

What is worth noting are the fights and clashes in Parliament, though they are unrelated to elections. Violence erupted in Parliament when MPs from the opposition parties were forced out of the chamber by armed police after they had challenged the president over a corruption scandal (Laing, 2015). Punches, hats, and furniture were thrown with several MPs taken to the hospital and treated for minor injuries (ibid.). In 2017, the National Defence Force was deployed to 
remove members of the Economic Freedom Front (EFF) during the annual State of the Nation Address.

South Africa has had fewer incidences of post-electoral violence because, borrowing from Burchard (2015), it arguably has stronger and more independent democratic institutions such as its Independent Electoral Commission, judiciary and media, than Nigeria. Furthermore, Burchard (2015) shows that the more violent and chaotic elections are, the more this limits both future participation in the election process as well as public involvement and support for democracy. Many developing countries have been plunged into violent conflict because of the lack of trust and partiality of electoral bodies. Thus it can be argued that voter apathy and poor citizen participation during elections in Nigeria are because of its violent experience during elections, which highlights the role of electoral institutions in both cases.

\section{Electoral Reputation}

In Nigeria, the electoral process has often been marred by significant flaws. For instance, in the immediate aftermath of the 2007 election, the late Nigerian President Umaru Yar'Adua acted on a personal conviction that the election that brought him into power was massively flawed with many irregularities. As a result he set up an Electoral Reform Committee (ERC), to investigate the irregularities experienced before, during and after the election and to make useful recommendations for future elections. The Committee issued its findings in December 2008, but the Nigerian government was slow to act and commenced reforms only in mid-2010 when the Parliament approved the first of several amendments to the electoral laws (Ploch 2012, p. 5). Gberie (2011, p. 1) summarises the 2011 elections in Nigeria as follows:

Nigerians went to the polls in April, to vote for members of the National Assembly, president and governors in the fourth nationwide elections to civil rule in 1999. The elections have been deemed to be the most organised, free and fair in the country's history, but they are far from flawless. International observers described the votes as a 'significant improvement' over the previous ones, which is a correct characterisation. Pre-election violence, including bomb attacks (which killed dozens of people) as well as the cumbersome new voting system used, in which registered voters had to be certified at designated polling booths in the morning and then vote in the afternoon, ensured that there was a low turn-out. 
The readiness of the Independent National Electoral Commission (INEC) was questioned at various times before and during the 2015 elections. This was especially when the smart card readers for voters' accreditation made available by the electoral body failed to work at several polling booths, causing initial tensions and even pandemonium in these areas. Notwithstanding, there are a few critical issues that call for urgent review and assessment in order to ensure future electoral successes. Firstly, it is imperative to examine how independent the electoral body is, and how impartial it is in discharging its duties. During the 2015 general elections, INEC displayed a degree of trust and independence, and that was obvious even as the incumbent federal government lost to an opposition party. Credit should be given to the national government for allowing INEC to go about its work without interference. Furthermore, the use of more experienced individuals and intellectuals as returning officers by INEC during the election also facilitated the electoral process and averted the challenges posed by inexperienced polling station agents. To this end INEC employed vice-chancellors of federal and state universities in Nigeria as returning officers.

South Africa's Electoral Commission has garnered a reputation for successfully conducting five national elections and has been recognised internationally for its efforts. The 2004 elections were an example of this as the requisite logistics and security measures to protect ballots were already in place prior to the elections. Furthermore there were no official observer delegations from the European Union or Commonwealth. According to the chairperson of the Commission this was because they felt comfortable enough with the elections process and that South Africa had reached a level which did not require observation from those bodies (Le Roux 2004). The presence of other observer missions from African countries such as Swaziland, Botswana, Namibia and the Democratic Republic of Congo, was for them to learn from the South African experience (Le Roux 2004). This is because South African elections provide a useful role model on how to successfully conduct and complete elections.

Though South Africa's track record is not unblemished, it has proved more credible and independent than its Nigerian counterpart. In 2016 the Constitutional Court noted that the IEC was 'inconsistent with the rule of law' in failing to secure addresses for all individuals on the country's voters' roll. The Court however emphasised that these inconsistencies did not render the elections invalid, thus further protecting the credibility of the institution. The IEC is also acknowledged for the fact that individuals can seek redress from the Electoral Court and it has shown its impartiality very strongly (Masterson 2016).

\section{Actors and Reasons for Electoral Violence}

Key distinguishing factors in both Nigeria and South Africa are the actors involved in electoral violence, and the reasons for this violence. Main players in Nigeria 
include the extremist group Boko Haram, which has greatly impeded election efforts in Northern Nigeria. Okafor $(2015$, p. 2) suggests that electoral violence is mostly perpetrated by the youth who are hired by politicians, particularly in previous elections in Nigeria. However, in some incidences teenagers and older adults have also become involved in political thuggery and are often used by politicians to destabilise electoral processes. Abah and Nwokwu (2015, pp. 41-42) suggested key predisposing factors for electoral violence in Nigeria to include: lack of fairness and transparency in the electoral process, non-credibility of the electoral body, ineffectiveness of law enforcement agencies, inordinate political ambition, ethnic politics, unemployment, the colourful nature of Nigerian politics, and of course, corruption. Some of these triggers of electoral violence are also apparent in South Africa, together with challenges to the law enforcement agencies, individual political ambitions, racialised politics, and unemployment.

Poverty and unemployment are crucial reasons for the youth to engage in or allow themselves to be used by aggrieved politicians during elections. Wealth disparities continue to plague both Nigeria and South Africa, but to varying degrees of intensity. For example, the ratio of the rate of poverty in Nigeria and South Africa is $55.2 \%$ to $39.6 \%$ respectively (UNDP, 2014). In South Africa, youth unemployment between the ages of $15-24$ is $51.5 \%$ and unemployment rate for those aged 15 years and older is $25.1 \%$ (UNDP, 2014). While there is no UNDP data on youth unemployment in Nigeria, the unemployment rate for those aged 15 years and older is $24 \%$ (UNDP, 2014). Dr. Yemi Kale, Statistician-General, National Bureau of Statistics (NBS), puts the current rate of unemployment in Nigeria at $24 \%$, while the poverty rate for 2009-2010 and 2013-2014 stands at $64.2 \%$ and $62.6 \%$ respectively (World Bank 2013, p. 9). 'The consequences of youth unemployment are arguably a major contributor to the myriad of social vices being inflicted on the country' (Daily Newswatch, 2013). Nowadays, it is often perceived that holding public office is an avenue for exploitation and self-enrichment - a development to the detriment of democracy in Africa (Opasina 2016, p. 43). Consequently, elections are seen as a 'do or die' affair, and politicians may go to any length in order to actualise their dreams. Nigeria is no exception. Idle youths are often sponsored by aggrieved politicians to disturb the public peace and to make the country ungovernable for their political opponents who are in power.

In South Africa, youths are not engaged in electoral violence to the same extent as in Nigeria, as the focus seems to be on other, more important and pressing issues. Protests since 2010 and more recently in 2016-2017 are due to issues with service delivery, university fees, labour issues, and calls for the resignation of the president. In the pre-election period these protests could easily be manipulated by politicians and the media thereby resulting in violence during elections; but this is not necessarily election-related violence. These protests are therefore in 
response to those political officials already in office and their failure to meet existing social and economic needs and demands. A review of election-related violence shows that these attacks usually involve gunmen targeting political candidates and activists in municipal elections, and protesters torching vehicles and tires while throwing rocks and looting shops because they disagree with a political candidate (Powell 2016). The assassination of political candidates has become a major source of concern, and because of the persistent threats to their safety political aspirants are frightened off from running for political office.

\section{One-Party Dominance}

This section examines power alternations in both countries and the factors for this. It also tries to understand the more recent shift in Nigeria and why South Africa, on the other hand, has failed to shift from a dominant one-party system.

Since 1999, Nigeria's Constitution and electoral acts have consistently supported multi-party systems as it has always been a multi-ethnic, multicultural and multi-religious nation. Bogaards (2004, p. 173) argues that 'multiparty elections do not lead automatically to multi-party systems'. In Bogaards' view, multi-party politics have led to the emergence of dominant parties and often to the dominance of a single political party, particularly in countries where governments have stayed in power for a long period. A case in point is the PDP in Nigeria, which had been the dominant ruling party since the beginning of the Fourth Republic in 1999 until the opposition APC unseated them in the 2015 general election. In South Africa the African National Congress (ANC) has ruled since 1994. Bogaards (2004, pp. 174-175) further observes that 'party dominance can usefully be distinguished by means of four criteria: the threshold for dominance; the inclusion or exclusion of opposition features; in presidential systems of government; the presence or absence of divided government; and the time-span taken into account.'

There are several lessons that can be learned from Nigeria's 2015 general elections. Firstly, the outcome of the elections saw an end to the domination of the one-party system. A large number of Nigerians wanted change and were determined to cast their votes for the main opposition party. Many reasons informed their decision; these included insecurity caused by the threat of Boko Haram, high unemployment, and the high rate of corruption. The main opposition party, the APC, also stepped up its game by strategically fielding candidates whom the population assumed would be able to meet their yearnings.

While South Africa also supports a multi-party democratic system, this has not been reflected in its political environment. The ANC remains the dominant political party as it has been since the country's first democratic elections after the 
end of the apartheid regime in 1994. The proportional representation (PR) system, allocates parliamentary seats to political parties based on the percentage of votes they obtain in elections. This has provided smaller parties with an opportunity to win seats, but it could also be a reason for the ANC's continued dominance in the different spheres of government. However, this dominance can be limited by the presence of constituency representatives at the local level.

Consequently the lack of a strong opposition in terms of numbers could hinder the achievement of a more democratic South Africa and a stronger multi-party system. However, the continued dominance of the ANC (although this is now dropping) shows that democracy can still grow. This is exemplified by the increase in popular dissatisfaction with the ANC since 1994, the rise of new parties like the EFF, led by Julius Malema, and the fact that the Democratic Alliance (DA) has been steadily obtaining more votes. While other parties like the Inkatha Freedom Party (IFP) and the African Christian Democratic Party (ACDP) lost votes by $2.4 \%$ and $0.8 \%$ in the 2009 elections respectively, the Congress of the People (COPE) emerged with $7.4 \%$ of the total votes even though it did not win any seats in the 2004 elections. According to Southall (2000), the continued dominance of a single party raises questions about its impact on minority groups and their interests, how its control can result in a corrupt and arrogant dictatorship, and whether the opposition can still hold the executive accountable. The ANCdominated Parliament is one example of the presence and strength of the party in political structures.

This dominance of the ANC even in the last elections stems from the fact that many black South Africans align with and vote for the party. This is particularly because of its role as the major liberation movement in opposing and bringing an end to the apartheid government. It is also part of a tripartite alliance with the South African Communist Party (SACP) and the Congress of South African Trade Unions (COSATU), which strengthened its dominance in the labour arena. The landslide victory by the ANC in 1994 showed the strong allegiance to the party and popular belief in its promise of a better future for many who had struggled and lost their loved ones during the apartheid era. The 1994 elections were noted as a positive development in South Africa's political history and according to Southall (2000) were generally deemed fair and free, though some viewed the process as set up to favour the ANC. These views were supported by factors such as the fact that the ANC used its control of public resources to improve its electoral advantage; in particular, the public news corporation, the SABC, was partisan in offering more support for the ANC than for opposition parties (Southall, 2000). While the ANC's dominance remains unrivalled and will remain so unless some significant shift in voter allegiance occurs, this raises issues of whether democracy will deliver anticipated gains for the electorate. 
Suffice it to say that apartheid has had a significant impact on the consolidation of democracy in South Africa. An important outcome of that regime has been the priority of subsequent democratic governments to redress the inequalities and marginalisation of the apartheid regime. This priority has been verbally expressed by presidents and key political actors and is grounded in the Constitution of the country. This Constitution is a key factor in consolidating democracy as it gives priority to the rights of all peoples and promotes the democratic principles of human dignity, freedom and equality. At the time of its drafting, it was important that the Constitution make a solid statement heralding the shift from a strong authoritarian government to one that respected the freedoms of individuals, including the freedom of expression and of religion, belief and opinion. In achieving the ideas of equality and human dignity, another significant development was the creation of the Black Empowerment Program (BEP) during the tenure of President Mbeki. This was considered to be part of the process of reversing the inequalities legislated by the apartheid government which 'systematically excluded African, Indian and "coloured" (mixed race) people from meaningful participation in the economy' (Smith 2009). While the $\mathrm{BEP}$ was created with the main aim of redressing the inequalities of apartheid, it has been criticised for benefitting only a select few loyal to the governing ANC.

The apartheid regime and experience showed the need for multi-party politics and the creation of human rights bodies and other Chapter 9 institutions as key components in the new democratic dispensation. These institutions include the Office of the Public Protector, the Commission for the Promotion and the Protection of the Rights of Cultural, Religious and Linguistic Communities (CRL Rights Commission) and the Commission of Gender Equality (CGE). Protecting this nascent democracy also required a transparent and effective IEC, which despite its challenges has delivered on its mandate to ensure free and fair elections. More importantly the rule of law was and is a recognisable and integral part of the new democratic South Africa. How these have fared since 1994 shows that more needs to be done to protect the democracy of the country against elements of the past from featuring in the current South African state. Lotshwao (2009, p. 970) states that due to the dominance of the ANC, the South African state is defined as:

An unresponsive and unaccountable government enabled by a dominant party that continues to win elections despite its increasing remoteness from the electorate; within the party, policies dictated by the leadership and prominent members; iron control exercised through Leninist principles by the party leadership over its cadres; and the consequent inability of these cadres deployed in various state institutions to hold the executive accountable or influence public policy. 
Suttner (2015) notes that those in government have been 'party to attacks on foreign migrants, defiance of the courts over Sudanese President Omar al-Bashir and other underminings of constitutionalism and general failures to provide basic needs like shelter, clean water and adequate educational facilities'.

\section{Political party dynamics: a comparison of Nigeria and South Africa}

Nigeria's first period of democratic governance, between 1960 and 1966, was modelled on the British parliamentary system. According to Omoweh and van den Boom (2005, p. 23), 'it was the inability of the people to grapple with politics, especially political competition along democratic line[s] since it was not on the agenda that accounted largely for the intervention of the military in the country's politics in January 1966'. Nigeria's Second Republic commenced in 1979 and lasted until 1983, and during that period the country adopted the presidential system of government modelled on the United States (US).

Unfortunately, that era was short-lived because of the military seizure of power in 1983 which resulted in a return to an authoritarian regime. Another attempt at returning to civilian rule was in 1993, when elections were held during the administration of General Ibrahim Babangida. During that time, Nigeria practised a two-party system and fielded candidates from two registered political parties, namely the Social Democratic Party (SDP) and National Republican Convention (NRC). Analysts agree that the 1993 presidential election, which could have culminated in a full return to civilian rule, was conducted in a free and fair manner. However, the election was annulled by the Babangida administration. The situation became increasingly tense and violence erupted in the aftermath of the annulment. It was not until 1999 that the administration of General Abdulsalami Abubakar handed over power to a democratically-elected president, Chief Olusegun Obasanjo. Since then there have been ups and downs and several challenges that successive civilian administrations have contended with, especially as a result of the military interregnum in Nigerian politics.

Political parties are often confronted with the task of conducting primaries aimed at selecting candidates to be their flagbearers in general elections. In Nigeria, it was not an easy task for the 28 registered political parties for the 2015 general election because there were disagreements and intra-party crises, which led to many cases of cross-carpeting ${ }^{2}$, or crossing the floor. During campaigns, politicians traded insults and used abusive language to intimidate their opponents. In many cases, this political intimidation led to violence and further tensions. Politicians used political debates to attack their opponents' personalities rather

2 The term connotes deflection from one political party to another. 
than their performances or political achievements. Many of the politicians also used thugs to disrupt rallies and campaigns.

Party cross-carpeting has become a major feature of Nigeria's political landscape. Aggrieved party members and aspiring political candidates frequently switch over to another political party when they have either lost at their party's primaries or fall out with the leadership of the political parties they previously belonged to. Of course, any opposition party would gladly welcome new members into its fold in order to build on its membership base, and the 2015 general election was no exception. For instance, in Oyo State ${ }^{3}$, a popular political figure in the opposition party, the PDP, lost at the state primaries. He then decided to cross over to the Labour Party, where he sought to become its flagbearer. Due to his influence and popularity, he was promptly admitted into the Labour Party where he subsequently became the flagbearer against the wish of other aspirants and founding party members.

South Africa has had its own share of defections, though fewer than in Nigeria. Major defections like the move of Julius Malema, former president of the ANC Youth League (ANCYL), to form the EFF, and other members to form $\mathrm{COPE}$, are some examples of party defectors. Recent events, however, show that challenges to the party will come from within and where key political actors leave their party this could potentially increase the strength, numbers and influence of opposition parties (Cheeseman 2017).

Several reasons can be cited as to why cross-carpeting might not be healthy for democracy, although people have the freedom to choose whichever political party they wish to join. In some cases, there have been situations where a political office holder would cross to a new party despite the fact that he or she was nominated and elected by the former party. Politicians are also fond of associating with and switching to the ruling party to avoid being probed for corrupt practices. It may be difficult for political office holders to probe party faithful and loyal members. One thing is certain; each political party has its own ideology and guiding principles and any a party member crossing to another party would have to contend with the ideology and principles of the new organisation.

Another important issue within political parties is the imposition of candidates as flagbearers by the so-called political godfathers during party primaries. There have been cases of election-rigging during the party nomination process. Sometimes incumbents use that platform to impose themselves to the detriment of democratic values. According to Ojukwu and Olaifa (2011, p. 31): 
Perhaps, the drama that was displayed by PDP on December 16, 2006 at the Eagle's Square, Abuja during the presidential primaries is still fresh in memories. Studies reveal that days prior to the primaries, it was obvious to many perceptive minds that Umaru Musa Yar'Adua, the then Governor of Katsina State and late entrant to the presidential race for the party, would emerge winner. This was not unconnected with the alleged 'behind-the-scene' deals that played out before the primaries. The development perhaps, made aspirants like Peter Odili, Donald Duke, Sam Egwu to suddenly withdraw from the race and perhaps forced to support Yar'Adua's candidacy. Anyhow, the party submitted that it only adopted 'consensus' approach at the eleventh hour.

In South Africa, the ANC has recently faced one of its biggest challenges with the president's removal of competent cabinet ministers and replacement with loyalists. One could however argue that in spite of public protests and public opposition by key members from the South African Communist Party (SACP), Congress of South African Trade Unions (COSATU) and the ANC, this has not significantly affected the cohesion and core of the party. This act (which some have referred to as clientelism and patronage politics), is already a common occurrence in Nigeria's political parties. It could move South Africa towards a less democratic system where groups and individuals push forward their personal interests in place of party or national interest. According to Cheeseman (2017), South Africa can thus learn from Nigeria that the entrenchment and positioning of politics and government founded on personal networks and clientelism can easily occur at the centre. To avoid this outcome, Cheeseman (2017) thus notes that it might be important to remove those individuals that encourage and fuel this system, in order to avoid normalising such a practice.

Political candidates often employ varied tactics to entice voters during electoral campaigns. One such is the politics of 'stomach infrastructure', which is not a new concept in the Nigerian polity. Several attempts have been made to define the concept of stomach infrastructure. For instance, Stober (2016, p. 455) is of the opinion that 'stomach infrastructure' is more about the people's welfare than the mere distribution of food items, customised or branded materials like t-shirts, umbrellas, and cash. Regardless, Nigerian politicians and political parties often employ the concept to win over voters. Unfortunately, there have been cases where politicians have handed out cash to voters on election days, and incidences of voter card buying from some electorate. Moreover, there have been cases where politicians resort to the use of political thugs to intimidate their opponents and mar the electoral process. In previous elections in Nigeria it was discovered that there is a connection between money in politics and electoral violence. Often, money is used by politicians to hire thugs and assassins, as well as to bribe election 
officials and security agents, in order to maim or kill political opponents and to disrupt the electoral process.

The role of money in South Africa's elections has garnered significant coverage, particularly regarding the sources of funds received by political parties, the desire to keep these private, and the view that the distribution processes of government funding to political parties is not fair. Attention to vote-buying within the ANC has been raised by prominent party politicians like ANC NEC member Lindiwe Sisulu (Bendile 2017) and current Deputy President Cyril Ramaphosa (Cohen \& Mkokeli 2017). Reported incidences of vote-buying in the ANC include the bulk purchase of membership cards and claiming non-existent members (ibid.). The use of government-funded food parcels has also been used to dredge up support for the ANC in by-elections (Bruce 2014). In a report by Bruce (2014) for the Community Agency for Social Enquiry (CASE), an interview respondent linked the DA to vote-buying and causing chaos at polling stations in the Western Cape. In 2013, Trade union COSATU stated that the DA's donation of one-million rand to e-tolling opposing group, Organisation Undoing Tax Abuse (OUTA) constituted vote-buying (Miya 2013). This action was also discouraged by South African National Roads Agency (SANRAL), which described it as making OUTA a political proxy (Miya 2013). These examples of vote-buying paint parties in a bad light and thus sully their reputations.

Another dimension of concern is the use of money in South Africa to hire thugs and killers. According to news reports (Olifant 2017; eNCA 2017; and Independent Online 2017) hitmen have been hired to carry out political assassinations and attack politicians, particularly at municipal level. According to eNCA (2017), witnesses in the Moerane Commission investigating political killings in Durban, testified that hitmen from the Glebelands hostel in Durban South had assassinated selected individuals. Their reasons ranged from politics, power, financial gain, criminality, and the failure of government and police-both the South African Police Service and the Durban metro police.

\section{Democratic Indicators}

Using O'Day's (2007) democratic indicators, as published by the National Democratic Institute (NDI), the authors of this paper carried out a comparative assessment of 60 democratic indicators in Nigeria and South Africa. They used recent democratic elections in both countries as shown below (see Table 1). ${ }^{4}$

4 The selections and views are those of two individual respondents with wide experience in the Nigerian and South African media and who have reported extensively on elections in both countries. Thus these views are not a reflection of the broader population of either country. 
These indicators show that democracy is stronger in South Africa than in Nigeria. The paper considers what these indicators are and why democracy is stronger in South Africa.

\section{Scale:}

Absolutely not $\quad 1$

Mostly not 2

Sometimes 3

Mostly yes 4

Absolutely yes $\quad 5$

Table 1

Comparative Assessment of Democratic Indicators between Nigeria and South Africa

\begin{tabular}{|c|c|c|c|}
\hline & Civil Rights & Nigeria & South Africa \\
\hline 1. & $\begin{array}{l}\text { Are people free of physical violation of their person } \\
\text { or property? }\end{array}$ & 2 & 4 \\
\hline 2. & $\begin{array}{l}\text { Do people have the freedom of movement, } \\
\text { expression, and association? }\end{array}$ & 3 & 4 \\
\hline \multirow[t]{2}{*}{3.} & $\begin{array}{l}\text { Do people have the freedom to practice their own } \\
\text { religion, language or culture? }\end{array}$ & 4 & 4 \\
\hline & Economic and Social Rights & & \\
\hline 1. & $\begin{array}{l}\text { Are basic necessities of life provided for, including } \\
\text { adequate food, shelter and clean water? }\end{array}$ & 2 & 3 \\
\hline 2. & $\begin{array}{l}\text { Is the right to a decent and adequate education } \\
\text { protected and provided for? }\end{array}$ & 2 & 3 \\
\hline 3. & $\begin{array}{l}\text { Do the citizens have the right to own property } \\
\text { or establish private businesses without undue } \\
\text { government influence? }\end{array}$ & 4 & 4 \\
\hline 4. & $\begin{array}{l}\text { Is there equal opportunity and absence of corruption } \\
\text { and exploitation in economic matters such as access } \\
\text { to higher education, employment, buying and selling } \\
\text { of products, running businesses, etc.? }\end{array}$ & 1 & 3 \\
\hline 5. & $\begin{array}{l}\text { Is the choice of residence, the choice of employment, } \\
\text { ability to get an education and other personal aspects } \\
\text { of an individual's life free of government control? }\end{array}$ & 3 & 4 \\
\hline & Civic and Political Participation & & \\
\hline
\end{tabular}




\begin{tabular}{|c|c|c|c|}
\hline 1. & $\begin{array}{l}\text { Is there a wide range of voluntary associations, } \\
\text { citizen groups, social movements, etc. and are they } \\
\text { independent of political parties and the government? }\end{array}$ & 2 & 4 \\
\hline 2. & $\begin{array}{l}\text { Do women participate in political life and public } \\
\text { office at all levels? }\end{array}$ & 2 & 4 \\
\hline 3. & $\begin{array}{l}\text { Do all social groups have equal access to public office } \\
\text { and are they fairly represented within it? }\end{array}$ & 1 & 2 \\
\hline 4. & $\begin{array}{l}\text { Is there academic freedom and is the educational } \\
\text { system free of extensive political influence or } \\
\text { indoctrination? }\end{array}$ & 2 & 4 \\
\hline 5. & $\begin{array}{l}\text { Is there open and free private discussion on all } \\
\text { issues? }\end{array}$ & 2 & 4 \\
\hline 6. & $\begin{array}{l}\text { Is there freedom of assembly, demonstration, and } \\
\text { open public discussion on all issues? }\end{array}$ & 3 & 4 \\
\hline \multirow[t]{2}{*}{7.} & $\begin{array}{l}\text { Are religious institutions, civic organizations, student } \\
\text { organizations, unions, and other organizations free of } \\
\text { government and political pressure? }\end{array}$ & 2 & 3 \\
\hline & Political Parties & & \\
\hline 1. & $\begin{array}{l}\text { Are political parties free to form, recruit members } \\
\text { and campaign for office? }\end{array}$ & 4 & 4 \\
\hline 2. & $\begin{array}{l}\text { Are opposition or non-governing parties free to } \\
\text { organize within the legislature and contribute to } \\
\text { government accountability? }\end{array}$ & 3 & 4 \\
\hline 3. & $\begin{array}{l}\text { Are party and candidate finances transparent and } \\
\text { free of corruption? }\end{array}$ & 1 & 2 \\
\hline \multirow[t]{2}{*}{4.} & $\begin{array}{l}\text { Are people's political choices free of interference by } \\
\text { government and military institutions? }\end{array}$ & 2 & 4 \\
\hline & Free and Fair Elections & & \\
\hline 1. & $\begin{array}{l}\text { Are electoral laws fair for all political parties and } \\
\text { groups? }\end{array}$ & 3 & 4 \\
\hline 2. & $\begin{array}{l}\text { Is registration and voting open to all citizens who } \\
\text { meet fair requirements? }\end{array}$ & 4 & 4 \\
\hline 3. & $\begin{array}{l}\text { Do the voters have a wide range of choices in the } \\
\text { election of political parties and candidates? }\end{array}$ & 3 & 4 \\
\hline 4. & $\begin{array}{l}\text { Are government officials in executive positions of } \\
\text { power subject to regular competitive elections? }\end{array}$ & 1 & 2 \\
\hline 5. & $\begin{array}{l}\text { Do all political parties and candidates have fair } \\
\text { access to participate in elections? }\end{array}$ & 3 & 3 \\
\hline
\end{tabular}




\begin{tabular}{|c|c|c|c|}
\hline 6. & $\begin{array}{l}\text { Are there equal campaigning opportunities for all } \\
\text { political parties including equal and fair access to the } \\
\text { media and means of communication with voters? }\end{array}$ & 2 & 3 \\
\hline 7. & $\begin{array}{l}\text { Is there fair polling and honest tabulation of the } \\
\text { ballots? }\end{array}$ & 3 & 4 \\
\hline 8. & $\begin{array}{l}\text { Do the government and other political forces accept } \\
\text { the results of the election? }\end{array}$ & 3 & 4 \\
\hline 9. & $\begin{array}{l}\text { 9. Is it possible or realistic for opposition parties to } \\
\text { win power through the election process? }\end{array}$ & 4 & 4 \\
\hline \multirow[t]{2}{*}{10.} & $\begin{array}{l}\text { 10. Is it possible for there to be a peaceful transfer of } \\
\text { power from the ruling party to the opposition? }\end{array}$ & 4 & 4 \\
\hline & Rule of Law & & \\
\hline 1. & $\begin{array}{l}\text { 1. Is there an independent judiciary free from } \\
\text { executive or outside pressures? }\end{array}$ & 2 & 4 \\
\hline 2. & $\begin{array}{l}\text { 2. Are all citizens, including those in positions of } \\
\text { power, treated equally under the law? }\end{array}$ & 2 & 3 \\
\hline 3. & $\begin{array}{l}\text { 3. Is there protection from police terror, unjustified } \\
\text { imprisonment, exile, or torture? }\end{array}$ & 3 & 4 \\
\hline \multirow[t]{2}{*}{4.} & $\begin{array}{l}\text { 4. Do citizens have confidence in the legal system to } \\
\text { deliver fair and effective justice? }\end{array}$ & 2 & 3 \\
\hline & Military and Police Control & & \\
\hline 1. & $\begin{array}{l}\text { Is political life free of police and military } \\
\text { involvement? }\end{array}$ & 3 & 3 \\
\hline 2. & $\begin{array}{l}\text { Are the police and security services publicly } \\
\text { accountable for their activities? }\end{array}$ & 2 & 2 \\
\hline 3. & $\begin{array}{l}\text { Do the army, police and security services reflect the } \\
\text { social composition of society at large? }\end{array}$ & 3 & 4 \\
\hline 4. & $\begin{array}{l}\text { Is the country free of paramilitary units, private } \\
\text { armies, warlords and criminal mafias? }\end{array}$ & 1 & 3 \\
\hline \multirow[t]{2}{*}{5.} & $\begin{array}{l}\text { Does the civilian government have effective control } \\
\text { over the police, security and armed forces? }\end{array}$ & 4 & 4 \\
\hline & Government Accountability & & \\
\hline 1. & $\begin{array}{l}\text { Are the executive agencies and their administrative } \\
\text { staff open to scrutiny and control by the elected } \\
\text { leaders? }\end{array}$ & 2 & 3 \\
\hline 2. & $\begin{array}{l}\text { Does the legislature have the power to scrutinize } \\
\text { executive officials and hold them accountable? }\end{array}$ & 3 & 4 \\
\hline
\end{tabular}




\begin{tabular}{|c|c|c|c|}
\hline 3. & $\begin{array}{l}\text { Does the legislature have the power to initiate, } \\
\text { scrutinize and amend legislation? }\end{array}$ & 4 & 3 \\
\hline 4. & $\begin{array}{l}\text { Are public budgets and expenditures transparent and } \\
\text { open to public scrutiny? }\end{array}$ & 3 & 4 \\
\hline 5. & $\begin{array}{l}\text { Do the citizens have the right of access to government } \\
\text { information? }\end{array}$ & 3 & 4 \\
\hline 6. & $\begin{array}{l}\text { Do freely elected representatives determine the } \\
\text { policies of the government? }\end{array}$ & 4 & 4 \\
\hline \multirow[t]{2}{*}{7.} & Is the government free of pervasive corruption? & 2 & 2 \\
\hline & Corruption & & \\
\hline 1. & $\begin{array}{l}\text { Is there adequate separation between public offices, } \\
\text { both elected and unelected and the political party } \\
\text { advantage, personal business, and family interests of } \\
\text { the office holders? }\end{array}$ & 3 & 1 \\
\hline 2. & $\begin{array}{l}\text { Are there effective arrangements for protecting office } \\
\text { holders and the public from bribery and corruption? }\end{array}$ & 1 & 2 \\
\hline 3. & $\begin{array}{l}\text { Are there rules and procedures effectively regulating } \\
\text { the influence of special interests in the financing of } \\
\text { elections, candidates and elected representatives? }\end{array}$ & 2 & 3 \\
\hline 4. & $\begin{array}{l}\text { Are powerful corporations and business interests } \\
\text { prevented from exerting undue influence over } \\
\text { public policy and kept free from the involvement in } \\
\text { corruption? }\end{array}$ & 2 & 3 \\
\hline \multirow[t]{2}{*}{5.} & $\begin{array}{l}\text { Do the people have confidence that public officials } \\
\text { and public services are free from corruption? }\end{array}$ & 1 & 1 \\
\hline & Media & & \\
\hline 1. & 1. Is the media independent from the government? & 3 & 4 \\
\hline 2. & $\begin{array}{l}\text { 2. Is the media representative of different opinions } \\
\text { and accessible to different sections of society? }\end{array}$ & 3 & 3 \\
\hline 3. & $\begin{array}{l}\text { 3. Are the media and other independent } \\
\text { organizations effective in investigating the } \\
\text { government, political parties and powerful } \\
\text { corporations? }\end{array}$ & 3 & 3 \\
\hline \multirow[t]{2}{*}{4.} & $\begin{array}{l}\text { 4. Are journalists free from restrictive laws, } \\
\text { harassment and intimidation? }\end{array}$ & 2 & 4 \\
\hline & Government Responsiveness & & \\
\hline 1. & $\begin{array}{l}\text { 1. Does the elected legislature reflect the social } \\
\text { composition of the population? }\end{array}$ & 2 & 4 \\
\hline
\end{tabular}




\begin{tabular}{|r|l|c|c|}
\hline 2. & $\begin{array}{l}\text { 2. Are there open and systematic procedures to allow } \\
\text { the public to consult on government policy and } \\
\text { legislation? }\end{array}$ & 2 & 4 \\
\hline 3. & $\begin{array}{l}\text { 3. Are elected representatives accessible to their } \\
\text { constituents? }\end{array}$ & 2 & 3 \\
\hline 4. & $\begin{array}{l}\text { 4. Are public services accessible and reliable for those } \\
\text { who need them? }\end{array}$ & 1 & 3 \\
\hline 5. & $\begin{array}{l}\text { 5. Do the people have confidence in the ability of } \\
\text { government to solve the main problems confronting } \\
\text { society? }\end{array}$ & $\begin{array}{l}\text { ( } \\
\text { influence the government? }\end{array}$ & $\mathbf{1 4 8}$ \\
\hline To the people have confidence in their own ability to & Total Points & 200 \\
\hline
\end{tabular}

Legend: Divide the total score by 60, to obtain a 'Democracy Score', according to the following scale:

Least democratic $1.0-1.9$

Less democratic $2.0-2.9$

More democratic $3.0-3.9$

Most democratic $4.0-5.0$

For Nigeria, the total count (148) divided by 60 gives 2.47. Nigeria ranks in the 'Less democratic' category. For South Africa, the total count (200) divided by 60 gives it a score of 3.33, thus ranking it in the 'More democratic' category. As we can see from the democratic indicator assessment, South Africa performed much better than Nigeria.

Several factors are responsible for Nigeria's performance in relation to democracy and the creation of public apathy. These include economic challenges such as the high rate of poverty and unemployment (Oluwatosin \& AbolarinEgbebi 2015, p. 41). According to these authors, 'political corruption is pandemic in Nigeria, manifesting as bureaucratic and electoral malpractices, bribery, fraud, embezzlement, extortion, favouritism and nepotism in the political scene' (Oluwatosin \& Abolarin-Egbebi, 2015). Also, voter apathy in Nigeria is due to a number of reasons such as the high rate of insecurity, political intimidation and lack of confidence in the electoral mechanism. These will be discussed in the next section of this paper.

While 1994 has been described as the beginning of democracy in South Africa, or at any rate the first step towards achieving that system of government, 23 years later much remains to be done. The 1994 elections were monumental and revolutionary as they brought together a racially divided electorate to vote for a government of their own choosing. It is also true that major changes have 
taken place and South Africa is in many regards much better than it was 23 years ago. Some of the positive changes from the apartheid-era include freedom of movement, a functioning government, one of the strongest constitutions in the world, economic transformation, and access to health and education. Noteworthy was the change in the balance of political power, which has led to black people dominating the political space.

While these developments are noteworthy, any assessment of democracy in South Africa raises some key challenges and issues. Poor service delivery, a high unemployment rate, the poor quality of public education and high levels of inequality pervade South African society. According to Afrobarometer (2015), unemployment $(44 \%)$, crime/security $(12 \%)$, and poverty ( $8 \%$ ) were identified as the most pressing problems facing the country between 2000 and 2011. Citizen approval of the government has been consistently low with regards to its efforts to alleviate poverty, inequality and unemployment, particularly between 2008 and 2011 (Afrobarometer, 2015).

There is a high prevalence of corruption in state institutions and amongst state officials. Together with the idea of the Protection of State Information Bill, which permits the protection of sensitive state information, this threatens the democratic advances made in South Africa's political and social context. Most notable was the Public Prosecutor's provisional report that President Jacob Zuma used public monies to upgrade his private home in Nkandla (Mail and Guardian 2013), something which has caused further friction between the ANC, DA and the EFF. The report, released in March 2014, noted that R246 million had been earmarked for the project with R215 million already spent (Madonsela 2014, p. 4). The report also noted that the security installations in Presidents Zuma's private residence far exceeded that of all his predecessors, from former President Botha to President Mbeki (Madonsela 2014, pp. 50-51). While a parliamentary committee on the matter concluded that the president did not need to repay the money, the DA and EFF joined together for a direct approach to the Constitutional Court on the Nkandla issue (Hunter 2015 and Gqirana 2015). According to Lotshwao (2009, p. 903), the accusation of corruption is further fuelled by the fact that there is a lack of intra-party democracy within the ANC, and this reduces the influence of supporters in the making of government policy and decisions. Lotshwao (ibid.) also notes that the ANC dominates institutions responsible for ensuring accountability.

\section{Voter Dynamics}

This section briefly examines voter dynamics, particularly issues of voter apathy and voter insecurity, as they relate to participation in elections. 


\section{Voter Apathy}

\section{Table 2}

Nigerian Population, Registration and Voter Turn-Out from 1999 to 2011

\begin{tabular}{|c|c|c|c|r|r|r|r|}
\hline Year & $\begin{array}{c}\text { Voter } \\
\text { Turn- } \\
\text { out }\end{array}$ & $\begin{array}{c}\text { Total } \\
\text { Vote }\end{array}$ & $\begin{array}{c}\text { Registra- } \\
\text { tion }\end{array}$ & $\begin{array}{c}\text { VAP } \\
\text { Turn- } \\
\text { out }\end{array}$ & $\begin{array}{c}\text { Voting } \\
\text { Age } \\
\text { Popula- } \\
\text { tion (VAP) }\end{array}$ & $\begin{array}{c}\text { Invalid } \\
\text { Votes }\end{array}$ & $\begin{array}{c}\text { Popula- } \\
\text { tion }\end{array}$ \\
\hline 2011 & $53.68 \%$ & 39469,484 & 73528040 & $48.32 \%$ & 81691751 & $3.19 \%$ & 155215,57 \\
\hline 2007 & $58 \%$ & $*$ & 61567036 & $*$ & 71004507 & $*$ & 13185973 \\
\hline 2003 & $69.08 \%$ & 42018735 & 60823022 & $65.33 \%$ & 64319246 & $6 \%$ & 12993491 \\
\hline 1999 & $52.26 \%$ & 30280052 & 57938945 & $57.36 \%$ & 52792781 & $1.4 \%$ & 10825835 \\
\hline
\end{tabular}

No official figure for indicators marked *

Source: Yusufu 2012, p.47

Table 2 above shows marked voter apathy in Nigeria. This is corroborated by the findings of Falade (2014, p. 22), which suggest that political participation, particularly voting during elections, is very low in Nigeria. Key reasons for voter apathy in Nigeria include: volatile security, political intimidation, poor political education, election rigging, staggered elections, voting system (accreditation being separated from voting especially in the 2011 general election) and a lack of confidence in the electoral system. However, a new policy with accreditation and simultaneous voting has been approved by the current INEC leadership with Professor Mahmood Yakubu as the chairman.

According to the IEC (2014) voter apathy in South Africa has declined significantly since 1994, from $86.87 \%$ in 1994 and $89.2 \%$ in 1999 to $73.48 \%$ in 2014 (Oyedemi \& Mahlatji, 2016). Oyeyemi and Mahlatji (2016) wrote that the level of voter apathy among young South Africans is particularly alarming because it is still a young democracy. Reasons for poor youth participation in elections include the constant battles with poverty, inequality and unemployment as well as dissatisfaction with the current political environment in all the three spheres of government (Tracey 2013; Oyedemi \& Mahlatji, 2016). A distinction must however be made between participation during elections, and community participation, the latter being a space where youths are actively involved through community protests (Oyedemi \& Mahlatji, 2016). 


\section{Voter Insecurity}

For myriad reasons, including that of insecurity because of the activities of Boko Haram in north-eastern Nigeria, analysts, stakeholders and onlookers projected a very slim likelihood of Nigeria holding a general election in 2015. Furthermore, the election management body INEC shocked Nigerians when it announced the postponement of the election dates by six weeks. While some supported this action, the majority of the population expressed their disappointment. The primary reason for the postponement was to give President Goodluck Jonathan's administration more time to tackle the threat of insurgency, particularly in the north. This was in order to provide an enabling and secure environment for all eligible voters to exercise their civic rights, and for INEC to complete the distribution of permanent voter's cards across the country. The presidential and parliamentary elections were finally held on 28 March 2015, while the gubernatorial and legislative elections took place on 11 April 2015. Nigerians went to the poll fearing the unknown. According to statistics, the number of registered voters was 67422005 (International IDEA, 2015). However, only 29432083 (representing $48 \%$ ) turned out to vote (ibid.). There were also recorded cases of violence and ballot box snatching at some accredited polling units across the country. There is a large gap between the number of registered voters compared to the number who actually turned out to vote. One reason for this, especially for those voters in insurgency-affected areas, was the fear of being attacked, although there was also the issue of voter apathy. Prospective voters need more than mere promises of peace and security. They want to see the government taking clear steps and realistic actions towards addressing security issues.

While South Africa has also had its fears of electoral violence and violent events during elections, it has for the most part been able to ensure the safety and security of its citizens. The South African Police Services (SAPS) have been instrumental in providing security for voters at various posts across the country to ensure that elections are free, safe and successful. For the fifth local government elections in 2016, SAPS announced the deployment of approximately 60000 officers, and a further 40000 mobile police to monitor over 22000 voting stations across the country (Orderson, 2016). This was due to fears of politically motivated violence as voter insecurity is often reflected in community attacks. This is especially true of local government elections, when the police have been called on to prevent violence and protect citizens.

\section{The Role of Technology in Elections}

The question of whether Nigeria is ready for electronic voting has been on the minds of stakeholders for some time. For instance, in preparation for the 2011 
election, INEC introduced the use of the biometric permanent voter's card (PVC), smart card reader machine and other technological innovations, in order to control electoral fraud. While a cross-section of Nigerians both in Nigeria and abroad believe that the country is ready for electronic voting, other observers think that several factors would hinder its successful implementation. They argue that factors such as an erratic power supply, which has deteriorated over the years, as well as huge logistical demands, could prevent the adoption of e-voting. Notwithstanding, Nigeria's National Assembly and in particular the Senate, has amended the 2010 Electoral Act in March 2017 to accommodate the use of smart card readers for the authentication of accredited voters. It has also approved the use of e-voting for future elections (Umoru 2017).

Technology has played a major role in South Africa's electoral process and is deemed useful in ensuring both credibility and transparency. Technology has been used to facilitate and improve voter registration processes and the entire voting process. It has become invaluable in ensuring that the process is effective and efficient. For instance, in the May 2014 elections, the IEC spokesperson noted the use of handheld scanners. These were used to scan the identification cards of voters, and other equipment was used to scan forms to provide the residential location of voters (Clottey 2014). This was critical for establishing the location or area of residence of voters. For its 1999 elections, technology was delivered via helicopter and by road to different communities in provinces like the Eastern Cape, to register individuals and ensure they voted in the national election. The IEC learnt some lessons from the challenges in the first democratic elections of 1994, such as poor security response, lack of capacity to manage the high numbers of voters and insufficient voting supplies (Huma 1999). By 1999 they were better prepared and had developed an information technology infrastructure to support the elections (Huma 1999). A comprehensive geographical information system (GIS) and maps were further developed for demarcating boundaries and directing voters to their specific voting booths (Huma 1999). The Electoral Commission has worked hard and in collaboration with various institutions to ensure the efficiency of South Africa's electoral system in collecting, tabulating and verifying results from various centres. So much so that it was described as surpassing anything the First World could achieve (Huma 1999).

\section{CONCLUSION AND RECOMMENDATIONS}

Nigeria

Voters and other stakeholders evinced considerable concern about the volatile security situation in Nigeria, given the incidents of violence which erupted in parts of the country before and after the recent elections. Adequate security would 
motivate voters and electoral officials to exercise their civic rights and perform their duties respectively.

The need to improve the electoral management bodies in Nigeria (Independent National Electoral Commission and State Independent Electoral Commission) is obvious. Again, training and capacity building of electoral officers has become necessary in order to enhance their efficiency. The EMBs should give more priority to addressing issues relating to logistics, which could affect the credibility of future elections. Electoral reform should be geared towards further amendments of the Constitution and Electoral Act, in order to improve compliance with international electoral standards. For instance, provisions should be made for the establishment of an electoral offences commission and a political parties registration and regulatory commission. Such commissions would ensure that political parties and candidates adhere strictly to electoral rules and regulations. Parties or candidates who flout electoral guidelines should be sanctioned and made to face the consequences. Also, the electoral act should make provisions for voters to lodge complaints when their electoral rights are being violated.

The use of smart card readers for voter accreditation in a country where power is erratic poses a huge challenge to the smooth running of electoral process. This was the case in the 2015 general election. Electoral officers found it difficult to fix the problem, resorting to the use of generators freely lent to them by nearby residents who were also frustrated by the slow process. Nigeria has been battling with an erratic power supply for years. In contrast, the power system in South Africa has been relatively stable.

Successive administrations in Nigeria have been unsuccessful in tackling the problem, despite several electoral promises. Future elections would run more smoothly when important logistics like the smart card readers function effectively without any hindrance. Election experts have agitated for electronic voting because it is faster and tends to be accessible. But there is some doubt as to whether developing nations are ready for electronic voting and whether they have the means and capacity to convert from manual counting. Nigerians living abroad are often side-lined, firstly from registering as voters, and secondly from the actual voting. Introducing electronic voting could address the disenfranchisement of the diaspora population because as citizens of the country they too should be entitled to vote.

\section{South Africa}

While South Africa has a very efficient, organised and technologically advanced system in place to limit or at best avoid any forms of electoral fraud, its electoral system is far from perfect. These imperfections and lapses are a result of its 
current electoral system. One criticism of proportional representation has been its contribution to the dominant one-party system which gives precedence to voting for political parties rather than individual representatives per constituency, the latter being a more transparent and democratic process. In the proportional system, parties have the upper hand in choosing the calibre and quality of individuals appointed to parliament, some of whom have questionable reputations and may lack the experience and skills for those positions. These individuals also focus solely on pushing forward the party's agenda. A representative democracy with individuals voted in by their constituents could offer a possible solution to the current system.

Attention must also be given to why people vote in the first place - that is to ensure that whoever they elect will focus on meeting their needs. These include access to economic opportunities, provision of quality and timely services, poverty alleviation and employment. It is important also that South Africa's democratic process be sustainable, thus a priority should be to rebuild voter trust and confidence in elected officials. In addition, improving the application and implementation of the rule of law; executive accountability; and avoiding abuse of executive power are integral to the sustainability of South Africa's electoral experience.

This paper provides a comparative analysis of elections and democracy in Nigeria and South Africa and key lessons from both. Most importantly, these have shown that elections in Africa still require significant political will, and human and financial commitment to ensure that these processes are safe, free, fair and successful. This includes financial resources to provide the right technology and increase the presence of security officials. It also involves improving accountability; ensuring the freedom of individuals to run for political office without fear for their safety; and increasing the efficiency of individuals and institutions tasked with running the elections. Secondly, both cases highlight the gaps and challenges to democracies which could inhibit further economic growth and development. These include corrupt governments, security concerns and disregard for the rule of law and the constitution. There is a lesson for less developed countries on the continent, that while a strong economy is important, as is the case in Nigeria and South Africa, weak state institutions and poor electoral processes remain a threat to democracy.

\section{----- REFERENCES}

Abah, E \& Nwokwu, P 2015, 'Political Violence and the Sustenance of Democracy in Nigeria', Journal of Humanities and Social Science, vol. 20, no. 11. 
Africa News Agency Reporter 2017, 'Hired thugs won't change SACP's “Zuma must go" stance', 13 April. Available from: www.iol.co.za [26 July 2017].

Afrobarometer 2015, "Confronting the "Triple Challenge": Findings on Poverty, Inequality, and Unemployment', Afrobarometer Surveys in South Africa, 19 February. Available from: www.afrobarometer.org [23 September 2015].

Alden, C \& Soko, M 2005, 'South Africa's Economic Relations with Africa: Hegemony and its Discontents', The Journal of Modern African Studies, vol. 43, no. 3, pp. 367-392.

Amabhungane 2013, 'Nkandla report: Zuma in the Deep End', Mail and Guardian, 29 November. Available from: www.mg.co.za [15 December 2015].

Babbie, ER 2017, The Basics of Social Research, $7^{\text {th }}$ ed., Cengage Learning, Massachusetts. Baker, B 1999, 'The Quality of African Democracy: Why and How it Should be Measured', Journal of Contemporary African Studies, vol. 17, no. 2, pp. 273-286. BBC News 2015, ‘\#ZumaMustFall: South Africans march against Jacob Zuma 16 December 2015'. Accessible from: www.bbc.co.uk [18 December 2015].

Bendile, D 2017, 'Lindiwe Sisulu takes tough stand on vote buying, fights for the ANCs soul', Mail and Guardian, 05 May. Available from: www.mg.co.za [3 September 2017].

Bogaards, M 2004, 'Counting Parties and Identifying Dominant Party Systems in Africa', European Journal of Political Research, no. 43, pp. 173-197.

Bruce, D 2014, 'Just singing and dancing? Intimidation and the manipulation of voters and the electoral process in the build-up to the 2014 elections', Community Agency for Social Enquiry (CASE), April 2014.

Burchard, SM 2015, 'Why Election Violence in Africa Matters', September 3, Institute of Defense Analyses: AfricaWatch, vol. 9.

Central Intelligence Agency 2012, The World Factbook: Nigeria, CIA Online Publications, Washington, D.C.. Available from: http://www.cia.gov/library/ publications/the-world-factbook/geos/ni.html [28 September 2012].

Cheeseman, N 2017, 'This is the beginning of the end of the ANC era', Daily Nation, 16 April 2017. Available from: www.nation.co.ke [5 May 2017]

Cilliers, J \& Aucoin, C 2016, 'Election Violence: Should South Africa be Worried', Institute for Security Studies, 20 June, 2016. Available from: www.issafrica.org [28 March 2017].

Clottey, P 2014, 'South Africa to Deploy Technology to Improve Technology', February 11. Available from: www.voanews.org [25 July 2017].

Cohen, C \& Mkokeli, S 2017, 'Corruption Threatens to Tear Apart S. Africa's Ruling Party', Bloomberg, January 27. Available from: www.bloomberg.co.za [3 September 2017].

eNews Channel Africa 2017, 'Commission hears that Glebelands Hitmen operate throughout KZN', 17 July, Available from: www.enca.com [25 July 2017]. 
Harmon, C 2013, 'Marshall Plan Necessary for Unemployment Rate', Daily Newswatch, 31 July. Available from: http://www.mydailynewswatchng.com/2013/07/31/ marshall-plan-necessary-for-unemployment-rate/ [31 October 2013].

Falade, D 2014, 'Political Participation in Nigerian Democracy: A Study of Some Selected Local Government Areas in Ondo State, Nigeria', Global Journal of Human Social Science, vol. 14, no. 8.

Gberie, L 2011, ‘The 2011 Election in Nigeria: A New Dawn?' Institute for Security Studies, Pretoria.

Gqirana, T 2015, 'DA Goes to Court Over Nkandla', Mail and Guardian, 19 August, Available from: www.mg.co.za [18 December 2015].

Heritage Foundation \& Wall Street Journal (Firm). 2017, The 2017 index of economic freedom, Heritage Foundation,Washington, D.C.

Huma, W 1999, 'South Africa's election technology coup', World \& I, vol. 14, no. 11, pp. 178-186.

Human Rights Watch 2011, 'Nigeria: Post-Election Violence Killed 800'. Available from: https://www.hrw.org/news/2011/05/16/nigeria-post-election-violencekilled-800 [29 August 2016].

Hunter, Q 2015, 'EFF's calculated moves to make Zuma pay', Mail and Guardian, 17 September. Available from: www.mg.co.za [18 December 2015].

IFES 200, EVER Report 6, IFES-NIGERIA, Abuja.

International IDEA 2015, African Elections Database, INEC Official Result, Stockholm. Iroha, J 2017, '29m Nigerians jobless as unemployment rate rises to $14.2 \%$ in Q4', Vanguard, June 6. Available from: www.vanguardngr.com [31 August 2017]. Laing, A 2015, 'Violence in South African Parliament as Opposition challenge President Jacob Zuma over Corruption', The Telegraph, 12 February. Available from: www.telegraph.co.uk [24 September 2015].

Le Roux, M 2004, 'IEC Confident of free and fair elections', Independent Online, 2 April, Available from: www.iol.co [6 April 2017].

Long, J 2010, 'Problem Elections in Emerging Democracies', Election Guide Digest. Available from: http://www.digest.electionguide.org/2010/07/19/longproblem-elections-in-emerging-democracies/ [23 February 2012].

Lotshwao, K 2009, ‘The Lack of Internal Party Democracy in the African National Congress: A Threat to the Consolidation of Democracy in South Africa', Journal of Southern African Studies, vol. 35, no. 4, pp. 901-914.

Madonsela, T 2014, 'Secure in Comfort', Office of the Public Protector, Pretoria.

Marais, H 2010, 'South Africa pushed to the Limit: The Political Economy of Change', UCT Press, Cape Town.

Masterson, G 2016, 'Why the IEC's reputation is so important', News24, 17 June. Available from: www.news24.com [6 April 2017].

Miya, N 2013, 'DA's donation to Outa is 'vote-buying' - Cosatu', SABC, June 7. Available from: www.sabc.co.za [3 September 2017]. 
O'Day, J 2007, Democratic Indicators, National Democratic Institute, Washington, D.C. Okafor, F 2015, 'Electoral Violence and the 2015 General Elections in Nigeria: The Implication Perspective', Afro Asian Journal of Social Sciences, vol. 6, no. 1, pp. $1-14$.

Ojukwu, C \& Olaifa, T 2011, ‘Challenges of Internal Democracy in Nigeria's Political Parties: The Bane of Intra-Party Conflicts in The People's Democratic Party of Nigeria', Global Journal of Human Social Science, vol. 11, no. 3.

Olifant, N 2017, 'Guns for Hire: Commission hears Glebelands hostel a hideout for paid killers', TimesLive, 18 July, 2017. Available at: www.timeslive.co.za [26 July 2017].

Oluwatosin, A \& Abolarin-Egbebi, A 2015, 'Poverty and the Sustainability of Democracy in Nigeria', IOSR Journal of Humanities and Social Science, vol. 20, no. 2.

Omodia, S 2009, 'Elections and Democratic Survival in the Fourth Republic in Nigeria', The Journal of Pan African Studies, vol. 3, no. 3, pp. 35-42.

Omoweh, D. \& Boom, D. van den 2005, Blocked Democracy in Africa: Experiment with Democratisation in Nigeria, 1999-2003, Konrad Adenauer Foundation, Abuja.

Opasina, O 2016, 'Traditional Institutions and the Challenge of Modernity in Nigeria and Côte d'Ivoire', International Journal on World Peace, vol. 33, no. 2.

Orderson, C 2016, 'South African Police to tighten security as election violence fears arise', The Africa Report, 28 July. Available from: www.theafricareport. com [31 August 2017].

Oyedemi, T \& Mahlatji, D 2016, "The "Born-free" Non-voting Youth: A Study of Voter Apathy among a Selected Cohort of South African Youth', Politikon, vol. 43, no. 3, pp. 311-323.

Ploch, L 2012. 'Nigeria: Elections and Issues for Congress', Congressional Research Service. Available from: http://www.crs.gov [22 February 2012].

Powell, A 2016, 'Violence Plagues South Africa Election', Voice of Africa Newws, July 29. Available from: www.voanews.com [28 March 2017].

Seethal, C 2012, 'South Africa's local government elections of 2011', South African Geographical Journal, vol. 94, no. 1, pp. 9-21.

Smith, D 2009, 'Challenges for Would-Be Black Economy', The Guardian, 31 July. Available from: www.theguardian.com [16 September 2015].

Southall, R 2000,'The State of Democracy in South Africa', Commonwealth and Comparative Politics, vol. 38, no. 3, pp. 147-170.

Statistics South Africa 2017, Quarterly Labour Force Survey - QLFS Q1:2017, Media Release, 1 June. Available from: http://www.statssa.gov.za [30 August 2017]. Stober, E 2016, 'Stomach Infrastructure: Lessons for Democracy and Good Governance', Management Dynamics in the Knowledge Economy, vol. 4, no. 3, pp. $449-460$. 
Stone, S 2015, 'South Africa is ready for Change says DA', Business Day Live, 13 June. [23 June 2015].

Suttner, R 2015, 'What is really at stake in an election of a woman as President?', Polity, 7 September, 2015. Available from: www.polity.org.za [23 July 2015].

This Day Live 2017, 'Dealing with Youth Unemployment', February 27. Available from: www.thisdaylive.com [30 August 2017].

Tracey, L 2013, 'What can be expected from Young Voters in South Africa's 2014 Elections?' ISS Today. September 17. Available from: www.issafrica.org [31 August 2017].

Uche, C \& Uche, O 2004, 'Oil and the Politics of Revenue Allocation in Nigeria', ASC Working Paper, no. 54.

Umoru, H 2019, 'Senate okays card reader electronic voting', Vanguard, 31 March, Available from: www.vanguardngr.com

UNDP 2014 Human Development Reports. Available from: www.hdr.undp.org [27 November 2015].

Walliman, N 2011, 'Your Research Project: Designing and Planning Your Work', 3rd ed., SAGE Publications, London.

World Bank 2013, 'Nigeria Economic Report', World Bank, Washington D.C.

Yusufu, AY 2012, 'Democracy and Political Apathy in Nigeria (1999-2011)', European Scientific Journal, September edition, vol. 8, no. 20, p. 7. 